\title{
RENDEMEN AKAR, BATANG DAN DAUN PASAK BUMI (Eurycoma longifolia Jack) SEBAGAI BAHAN BAKU OBAT HERBAL
}

\section{THE RENDEMENT OF ROOTS, STEAMS, AND LEAVES OF PASAK BUMI (Eurycoma longifolia Jack) AS HERBAL MEDICINE INGREDIENTS}

\author{
Supartini ${ }^{1 *}$ dan Deddy Dwi Nur Cahyono ${ }^{2)}$ \\ ${ }^{1)}$ Balai Besar Penelitian dan Pengembangan Ekosistem Hutan Dipterokarpa \\ Jalan Abdul Wahab Syahrani No. 68 Sempaja, Samarinda \\ ${ }^{2)}$ Balai Penelitian dan Pengembangan Teknologi Perbenihan Tanaman Hutan \\ Jalan Pakuan Ciheuleut PO BOX 105, Bogor 16001 Jawa Barat \\ E-mail : tini_b2pd@yahoo.com/tini.b2pd@gmail.com
}

\begin{abstract}
ABSTRAK
Pasak bumi merupakan salah satu jenis tanaman berkhasiat obat. Informasi rendemen simplisia, rendemen ekstrak dan kandungan fitokimia dari akar, batang dan daun tanaman Pasak bumi diperlukan untuk mengoptimalkan bahan baku dan meminimalkan limbah pemanenan sehingga tanaman dapat digunakan berkelanjutan. Penelitian bertujuan untuk mengetahui rendemen simplisia, rendemen ekstrak dan fitokimia tanaman pasak bumi pada bagian akar, batang dan daun. Sampel akar, batang dan daun dilakukan pengukuran kadar air, perbandingan akar dan tinggi tanaman, perhitungan rendemen simplisia perbagian dan pertotal bagian, rendemen ekstrak dan pengujian fitokimia. Metode pengeringan dilakukan pada suhu ruangan dan oven. Ekstraksi sampel menggunakan pelarut etanol, air dan etil asetet dengan metode maserasi. Skrining fitokimia meliputi pemeriksaan alkaloid, flavanoid, saponin, tanin, triterpenoid, steroid, karotenoid dan kumarin. Data hasil pengukuran dan perhitungan ditabulasi menggunakan Microsoft Excel dan dianalisis secara deskriptif. Hasil penelitian menunjukkan bahwa susutnya kadar air segar ke kering udara pada daun, batang dan akar sebanyak $149,41 \%, 72,95 \%$ dan $83,45 \%$. Tanaman dengan tinggi lebih dari 200 $\mathrm{cm}$ memiliki perbandingan akar dan tinggi tanaman terkecil $(0,38)$. Rendemen perbagian pada daun $(38,75 \%)$, batang $(48,5 \%)$ dan akar $(48,82 \%)$ dan rendemen pertotal bagian pada daun $(4,87 \%)$, batang $(25,05 \%)$ dan akar $(13,80 \%)$, sisanya ranting. Ekstrak akar, batang dan daun dengan pelarut air memiliki rendemen yang lebih tinggi dibandingkan dengan pelarut etanol. Kandungan bioaktif ekstrak akar dan batang adalah alkaloid, tanin, triterpenoid, karotenoid dan kumarin, sedangkan pada ekstrak daun yaitu flavonoid, saponin, tanin, triterpenoid, karotenoid, dan kumarin. Tanaman ini berpotensi sebagai antimalaria, antidiabetes, antidiare, antijamur, antibakteri, antivirus, pengobatan kerusakan hati, gangguan menstruasi, antioksidan, dan antiimflamasi.
\end{abstract}

Kata kunci: Eurycoma longifolia, fitokimia, obat herbal, Pasak bumi, rendemen.

\section{ABSTRACT}

Pasak bumi (Eurycoma longifolia Jack) is one species of medicinal plants. Information simplicia rendement, extract rendement, and phytochemical compound of pasak bumi roots, stems and leaves were needed in order to optimize raw materials and minimize waste 
harvesting of pasak bumi, so that these plants can be used sustainably. This study aims to determine simplicia rendement, extract rendement, and phytochemistry of pasak bumi plants in the roots, stems, and leaves. Samples of roots, stems, and leaves of Pasak bumi were measured by water content, the ratio of roots, and stem length, simplicia rendements by part and total plant, extract rendements, and phytochemical screening. The drying method was carried out at room and oven temperature. Sample extraction using ethanol, water, and ethyl acetate solvent by maceration method. Phytochemical screening includes examination of alkaloids, flavonoids, saponins, tannins, triterpenoids, steroids, carotenoids, and coumarin. Measurement and calculation data are tabulated using Microsoft Excel and analyzed descriptively. The results showed that the shrinkage of freshwater to dry air in leaves, stems, and roots was $149.41 \%, 72.95 \%$, and $83.45 \%$, respectively. Pasak bumi with height of more than $200 \mathrm{~cm}$ have the smallest ratio of roots and stem length, that is 0.38 . Simplicia rendements by parts on leaves, stems and roots were $38.75 \%, 48.5 \%$, and $48.82 \%$, respectively and total simplicia rendements of leaves, stems and roots were $4.87 \%, 25.05 \%$, and $13,80 \%$ respectively, the remaining twigs. The water-soluble extract rendement of roots, stems, and leaves is higher than the ethanol extract. Bioactive ingredients in roots and stems extracts contained alkaloids, tannins, triterpenoids, carotenoids and coumarin, whereas leaves extracts are flavonoids, saponins, tannins, triterpenoids, carotenoids, and coumarin. This plant has potential as antimalarial, antidiabetic, antidiarrheal, antifungal, antibacterial, antiviral, treatment of liver damage, menstrual disorders, antioxidants, and anti-inflammatory.

Keywords: Eurycoma longifolia, herbal medicine, Pasak bumi, phytocemical, rendement.

\section{PENDAHULUAN}

bat herbal adalah obat yang berasal dari tumbuhan yang diproses tanpa menggunakan zat kimia yang dapat berupa serbuk, pil atau cairan untuk mengobati penyakit dengan efek samping minim (Wulandari et al., 2017). Pasak bumi merupakan salah satu obat herbal dari tanaman hutan yang telah lama dimanfaatkan oleh masyarakat. Jenis pasak bumi yang umumnya digunakan berasal dari jenis Eurycoma longifolia Jack (famili Simaroubaceae). Semua organ tumbuhan Pasak Bumi (akar, batang dan daun) dapat dimanfaatkan sebagai bahan baku obat. Masyarakat pedalaman Suku Dayak Tunjung di Kalimantan Timur memanfaatkan Pasak Bumi bagian akar untuk pengobatan malaria dengan cara direbus dan diminum airnya (Setyowati, 2010). Silalahi \& Nisyawati (2015) menyatakan bahwa masyarakat lokal di Desa Peadundung, Batak (Sumatera Utara) lebih sering memanfaatkan Pasak Bumi bagian daun dibandingkan dengan bagian lainnya yang digunakan sebagai obat sakit perut. Kulit dan batang Pasak Bumi digunakan untuk mengobati demam dan sariawan (Hasibuan et al., 2016). Hasil kajian farmakologis membuktikan banyak sekali manfaat yang dapat diperoleh dari pasak bumi. Manfaat tersebut diantaranya sebagai obat afrosidiak (Pratomo, 2012), memiliki senyawa antikanker (Nurani, 2011), potensial sebagai antibakteri (Farouk \& Benafri, 2007), untuk antimalaria dan antileukemia (Yusuf et al., 2013), untuk fertilitas (Siburian \& Marlinza, 2009; Abdulghani et al., 2012), untuk osteoporosis (Effendy et al., 2012), serta memiliki senyawa antiinflamasi (Tran et al., 2014).

Kandungan senyawa dalam tanaman pasak bumi telah diteliti dan dapat dijadikan sebagai bahan baku obat. E. longifolia mengandung quassinoids, turunan squalene, biphenylneolignans, alkaloid beta-karbolin, tipe tirucallane triterpen dan alkaloid canthin-6one, dengan quassinoid memiliki jumlah tertinggi (Mohamed et al., 2015). Senyawa golongan quassinoid yaitu eurycomaosida pada ekstrak etil asetat kulit batang pasak bumi 
mempunyai aktivitas antiinflamasi (Widiyantoro, 2014) mendukung pemanfaatannya sebagai obat antiradang. Akar pasak bumi yang mengandung antioksidan (eurikomalakton, eurikomanon dan eurikomanol) memiliki efek menjaga kesehatan hati (Adikusuma \& Bachri, 2014). Ekstrak air dari akar E. longifolia yang mengandung bioktif peptida secara signifikan dapat meningkatkan volume air mani, konsentrasi dan morfologi sperma (Ismail \& Imran, 2010), hal ini mendukung pemanfaatannya sebagai obat afrodisiak. Peningkatan produksi air susu induk Mencit setelah pemberian sediaan akar pasak bumi selama masa laktasi (Panjaitan et al., 2009) mendukung pemanfaatannya sebagai tonik ibu setelah melahirkan. Kemampuan ekstrak daun pasak bumi dalam menghambat pertumbuhan Escherichia coli mendukung pemanfaatannya sebagai obat sakit perut dan kemampuan menghambat pertumbuhan Salmonella typhi berhubungan dengan manfaatnya sebagai obat demam khususnya demam tifus (Farouk \& Benafri, 2007).

Kebutuhan pasak bumi sebagai bahan baku obat masih diperoleh dan berasal dari hutan (Zuhud \& Hikmat, 2009). Permintaan pasar dari pasak bumi sebagai bahan baku obat yang meningkat mendorong terjadinya eksploitasi jenis ini. Pemanfaatan tanaman pasak bumi sebagian besar masih terbatas pada bagian akarnya. Pemanenan pasak bumi dengan tujuan memanfaatkan akar, tentunya akan mematikan tanaman pasak bumi karena teknik panen yang dilakukan dengan cara mencabut akar sekaligus seluruh bagian tanamannya. Eksploitasi tanpa diiringi tindakan budidaya dapat menyebabkan populasi menjadi langka. Pemanfaatan pasak bumi dari hasil budidaya merupakan hal yang mutlak dilakukan untuk tetap menjaga ketersediaan jenis tersebut.

Budidaya pasak bumi dapat dilakukan secara generatif maupun vegetatif. Secara generatif yaitu dengan benih (Fitriani et al., 2017), cabutan (Cahyono \& Rayan, 2016) dan puteran (Suharti et al., 2019). Sedangkan secara vegetatif dapat menggunakan teknik stek pucuk (Susilowati et al., 2012), stek batang (Achmad, 2016) dan kultur jaringan (Rosmaina et al., 2015). Upaya budidaya dengan membangun plot penanaman pasak bumi telah dilakukan oleh Balai Besar Penelitian dan Pengembangan Ekosistem Hutan Dipterokarpa (B2P2EHD). Pembangunan plot penanaman dari bahan generatif berupa benih pada tahun 2010 dilakukan di Kawasan Hutan Dengan Tujuan Khusus (KHDTK) Samboja (Rayan et al., 2010). Pada saat penanaman, bibit dengan tinggi $\pm 13 \mathrm{~cm}$ ditanam dengan jarak $1,5 \mathrm{~m} \times 1,5$ m. Adinugroho et al. (2007) melaporkan bahwa KHDTK Samboja secara administratif berada di Kelurahan Sungai Merdeka, Kecamatan Samboja, Kabupaten Kutai Kartanegara, secara geografis berada di $00^{\circ} 59,657^{\prime} \mathrm{LS}$ dan $116^{\circ} 57,644^{\prime} \mathrm{BT}$ dengan jenis tanah termasuk podsolik merah kuning, tipe iklim A berdasarkan klasifikasi Schmidt dan Ferguson, suhu udara berkisar antara $26^{\circ}-28^{\circ} \mathrm{C}$, kelembaban rata-rata berkisar antara $63-69 \%$, rata-rata curah hujan tahunan berkisar 1.682-2.314 mm dengan jumlah hari hujan 72-154 hari dan berada pada ketinggian antara 50-150 mdpl.

Informasi rendemen simplisia dan rendemen ekstrak dari akar, batang dan daun tanaman Pasak bumi diperlukan untuk mengoptimalkan bahan baku dan meminimalkan limbah pemanenan sehingga tanaman ini dapat digunakan secara berkelanjutan. Informasi kandungan fitokimia ekstrak dari akar, batang dan daun tanaman Pasak bumi diperlukan untuk mengetahui potensi pengembangan produk berdasarkan khasiatnya. Penelitian ini bertujuan untuk mengetahui rendemen simplisia, rendemen ekstrak dan fitokimia tanaman pasak bumi (Eurycoma longifolia Jack) pada bagian akar, batang dan daun.

\section{BAHAN DAN METODE}

\section{Bahan dan Alat}

Pasak bumi yang digunakan dalam penelitian ini merupakan tanaman yang telah berumur 7 tahun 10 bulan bagian akar, batang daun daun. Bahan lain yang juga digunakan 
yaitu etanol, bismuth (III) nitrat, asam asetat, aquades, kalium iodida, $\mathrm{HCl}, \mathrm{NaOH}$ dan timbal asetat. Alat yang digunakan meliputi kaliper, meteran, timbangan digital, bejana maserasi, batang pengaduk, rotary vacum evaporator, oven, tabung reaksi, gelas ukur dan alat penggiling.

\section{Metode}

Pengujian sampel kadar air dan rendemen simplisia dilaksanakan di Laboratorium Balai Besar Penelitian dan Pengembangan Ekosistem Hutan Dipterokarpa (B2P2EHD) di Samarinda. Pengujian rendemen ekstrak dan fitokimia dilakukan di Laboratorium Kimia Hasil Hutan, Fakultas Kehutanan Universitas Mulawarman, Samarinda. Penelitian dilaksanakan selama 5 bulan yaitu bulan Maret sampai dengan Agustus 2018. Tanaman pasak bumi diukur tingginya yaitu dari pucuk tanaman hingga pangkal batang yang berbatasan dengan tanah. Tanaman kemudian dicabut keseluruhan bagiannya tanpa merusak. Sampel kemudian dipotong menjadi bagian-bagian akar, batang dan daun. Ulangan sampel yang digunakan sebanyak 9 tanaman. Pengukuran panjang akar dilakukan, penimbangan berat basah (akar, batang dan daun), pengeringan sampel kering udara selama 2 minggu pada suhu $25^{\circ} \mathrm{C}$ di dalam ruangan dan pengovenan sampel (daun dioven pada suhu $50^{\circ} \mathrm{C}$ (Adri \& Hersoelistyorini, 2013) selama 24 jam, sedangkan batang dan akar dioven pada suhu $105^{\circ} \mathrm{C}$ selama 72 jam). Karakteristik sampel pasak bumi meliputi karakteristik tanaman, kadar air, perbandingan akar dan batang. Perhitungan kadar air basah (1), kadar air kering udara (2), perbandingan akar dan tinggi tanaman (3), rendemen perbagian (4) dan rendemen pertotal bagian (5) seperti persamaan di bawah.

a. Perhitungan kadar air (Wulandari et al., 2017)

$$
\begin{array}{r}
\text { Kadar air basah }=\frac{\mathrm{Wb}-\mathrm{Wo}}{\mathrm{Wo}}(1) \\
\text { Kadar air kering udara }=\frac{\mathrm{Wku}-\mathrm{Wo}}{\mathrm{Wo}}(2)
\end{array}
$$

Keterangan: $W_{b}=$ berat basah $(g), W_{k u}=$ berat kering udara $(g), W_{o}=$ berat kering oven $(g)$

b. Perbandingan akar dan tinggi tanaman (Musa et al., 2005)

Perbandingan akar dan tinggi tanaman $=\frac{\text { panjang akar }(\mathrm{cm})}{\text { tinggi tanaman }(\mathrm{cm})}(3)$

c. Rendemen simplisia perbagian (Safrina \& Priyambodo, 2018)

$$
\text { Rendemensimplisia per bagian (akar, batang, daun) }=\frac{\text { berat kering oven (gram) }}{\text { berat basah (gram) }} x 100 \%
$$

d. Rendemen simplisia pertotal bagian (Safrina \& Priyambodo, 2018)

$$
\text { Rendemensimplisia pertotal bagian }=\frac{\text { berat kering oven perbagian }(\text { gram })}{\text { berat kering oven total }(\text { gram })} \times 100 \%
$$

Pengukuran faktor kelembaban (Moisture Factor) ekstrak menggunakan standart TAPPI T264 om-88. Prosedur pengukuran faktor kelembaban adalah sebagai berikut: 1) Penimbangan botol yang digunakan; 2) Serbuk sampel dimasukkan sebanyak $\pm 2 \mathrm{~g}$ ke dalam botol dan di oven pada temperatur $100 \pm 2{ }^{\circ} \mathrm{C}$ selama 24 jam, kemudian didinginkan dalam desikator selama \pm 15 menit dan ditimbang kembali; 3) Pengeringan di dalam oven dilakukan setelah 2 jam lalu didinginkan dan ditimbang; 4) Penimbangan dan pengeringan dilakukan hingga beratnya konstan.

e. Perhitungan Faktor kelembaban (Balebu et al., 2002)

$$
\text { Faktor kelembaban }(\mathrm{MF}) \text { ekstrak }=\frac{\text { berat sampel kering tanur }(\mathrm{g})}{\text { berat sampel mula-mula }(\mathrm{g})}(6)
$$


Sampel serbuk akar, batang dan daun Pasak bumi sebanyak $20 \mathrm{~g}$ dilarutkan pada etanol $96 \%$ sebanyak $150 \mathrm{~mL}$ untuk pembuatan ekstrak etanol kemudian dilakukan pengadukan shaker selama 1 × 24 jam pada suhu ruang. Selanjutnya larutan disaring dan dipekatkan dalam oven bersuhu $40^{\circ} \mathrm{C}$ sehingga didapatkan crude extract etanol dari masingmasing sampel. Sampel serbuk akar, batang dan daun pasak bumi sebanyak $5 \mathrm{~g}$ dilarutkan pada air panas sebanyak $100 \mathrm{~mL}$, kemudian didiamkan hingga dingin. Selanjutnya larutan disaring dan dipekatkan dalam oven bersuhu $40^{\circ} \mathrm{C}$ sehingga didapatkan crude extract air dari masing-masing sampel.

f. Rendemen ekstrak (Sani et al., 2014)

$$
\% \text { Rendemen ekstrak }=\frac{\text { berat ekstrak }(\mathrm{g})}{\text { berat sampel awal (g) } x M F} \times 100 \%(7)
$$

Pengujian fitokimia ekstrak pasak bumi bagian akar, batang dan dilakukan di laboratorium Kimia Hasil Hutan, Fakultas Kehutanan Universitas Mulamarwan, Samarinda. Pengujian fitokimia untuk ekstrak etanol menggunakan sampel ekstrak sebanyak $1 \mathrm{~mL}$, sampel dimasukkan dalam tabung reaksi, kemudian dilarutkan dalam $14 \mathrm{~mL}$ etanol dan selanjutkan diuji fitokimianya. Pengujian fitokimia dari ekstrak Pasak bumi pelarut air menggunakan serbuk Pasak bumi sebanyak 500 mg, sampel dimasukkan dalam tabung reaksi, kemudian dilarutkan dalam $12 \mathrm{~mL}$ aquades dan selanjutnya diuji fitokimianya. Pengujian fitokimia dari ekstrak Pasak bumi pelarut etil asetat menggunakan ekstrak sebanyak $5 \mathrm{mg}$, sampel dimasukkan dalam tabung reaksi, kemudian dilarutkan dalam 10 $\mathrm{mL}$ etil asetat dan selanjutnya diuji fitokimianya. Analisis fitokimia dilakukan dengan uji perubahan warna yang mengacu untuk menguji adanya senyawa aktif yang meliputi alkaloid flavonoid, tanin, saponin, triterpenoid dan steroid (Ikalinus et al., 2015), karotenoid dan kumarin (Senthilmurugan et al., 2013). Data hasil pengukuran dan perhitungan ditabulasi menggunakan Microsoft Excel dan kemudian dianalisis deskriptif.

\section{HASIL DAN PEMBAHASAN}

\section{Karakteristik Tanaman}

Pasak bumi (Eurycoma longifolia) termasuk dalam suku Simaroubaceae. Tanaman pasak bumi umur 7 tahun memiliki kisaran diameter $15-29 \mathrm{~mm}$, tinggi $92-223 \mathrm{~cm}$, rerata berat daun, batang dan akar sebesar $28 \mathrm{~g}, 144 \mathrm{~g}$ dan $79 \mathrm{~g}$. Karakteristik daun, batang dan akar disajikan pada Gambar 1. Pertumbuhan tinggi dan diameter tanaman pasak bumi tiap tahunnya sampai tahun ke-7 ini berkisar $17,67 \mathrm{~cm}$ dan 3,09 mm. Tumbuhan pasak bumi dapat berupa perdu atau pohon kecil yang tingginya dapat mencapai $10 \mathrm{~m}$, memiliki daun berbentuk lanset dengan tepi rata berukuran 2,5-14,2 X 0,7 -4,5 cm, daun majemuk menyirip ganjil dengan jumlah anak daun 11- 38, batang umumnya tidak bercabang dan berwarna coklat keabu-abuan (Kartikawati, 2014). Pada tingkat semai, pasak bumi mengelompok di bawah tajuk atau pada tumbuhan muda tidak menyukai cahaya yang terlalu banyak, tetapi pada tingkat pohon memerlukan cahaya langsung (Heriyanto et al., 2006). 


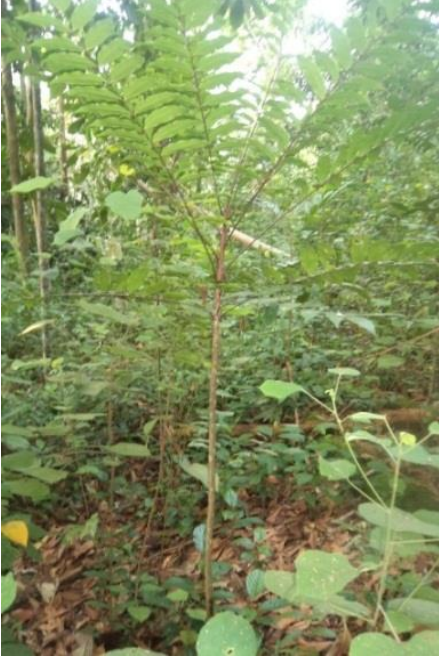

(a)

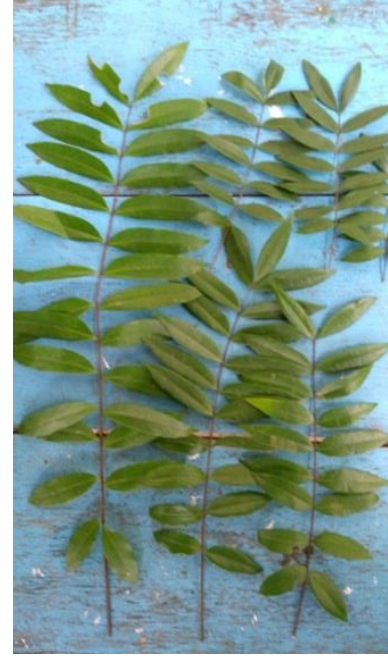

(b)

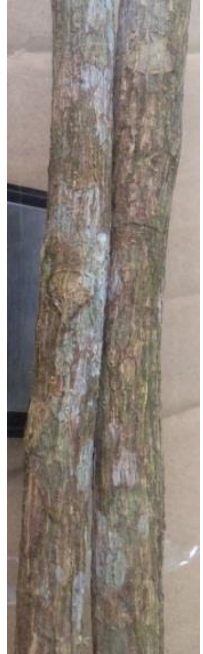

(c)

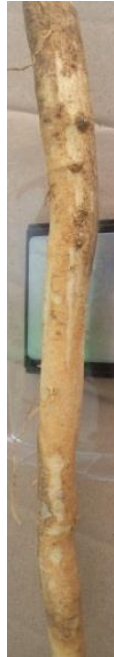

(d)

Gambar 1. Kharakteristik tanaman pasak bumi umur 7 tahun (pohon (a); daun (b); batang (c); dan

\section{Kadar Air} akar (d).

Daun memiliki kadar air segar tertinggi dibandingkan batang dan akar (Gambar 2). Setelah melalui perlakuan kering udara, justru bagian daun memiliki kadar air terendah. Susutnya kadar air daun sebanyak 149,41\% menunjukkan bahwa daun merupakan bagian yang paling mudah dikeringkan dibanding lainnya. Selain itu, kadar air kering udara daun $\leq 10 \%$ memenuhi persyaratan bahan baku obat nabati yang dikeringkan/simplisia (BPOM, 2014). Apabila daun pasak bumi akan dikembangkan menjadi produk seperti teh, maka telah memenuhi kadar air untuk standar mutu teh $8 \%$ (SNI 3945, 2016). Standar kadar air yang rendah tersebut untuk menghindari terjadinya reaksi enzimatis serta pertumbuhan jamur dan bakteri ketika simplisia disimpan (Katno, 2008). Aktivitas reaksi enzim relatif berhenti pada kadar air telah mencapai $20 \%$, namun akan mudah aktif kembali bila berhubungan dengan udara luar sehingga sebaiknya kadar air daun teh yang dikeringkan mencapai 3\% (Sembiring, 2009). Pemanfaatan daun pasak bumi sebagai bahan baku obat berupa teh herbal perlu untuk dikembangkan karena ekstrak pelarut air dari daun $E$. longifolia memiliki kemampuan reduksi penyerapan DPPH atau antioksidan sebesar 49\% (Supartini \& Maharani, 2017). Selain upaya pengoptimalan bahan baku dan diversifikasi produk, pemanfaatan daun sebagai bahan baku obat herbal mempertimbangkan aspek konservasi dari tanaman Pasak bumi sehingga bahan baku dapat diperoleh secara berkelanjutan.

Kadar air kering udara pada bagian batang dan akar dalam percobaan ini masih diatas $10 \%$. Proses pengeringan hanya menghasilkan susutnya kadar air batang $72,95 \%$ dan akar $83,45 \%$. Hal ini dapat disebabkan karena ketebalan bahan yang lebih rapat dibanding daun. Diperlukan proses pengeringan lebih lanjut untuk mendapatkan kondisi kering udara dibawah $10 \%$. Selain itu, bahan sampel yang diperkecil dimensinya dengan dicacah, dapat membantu mempercepat proses pengeringan dan kadar air dapat dicapai menjadi $6 \%$ (Riyani, 2016). 


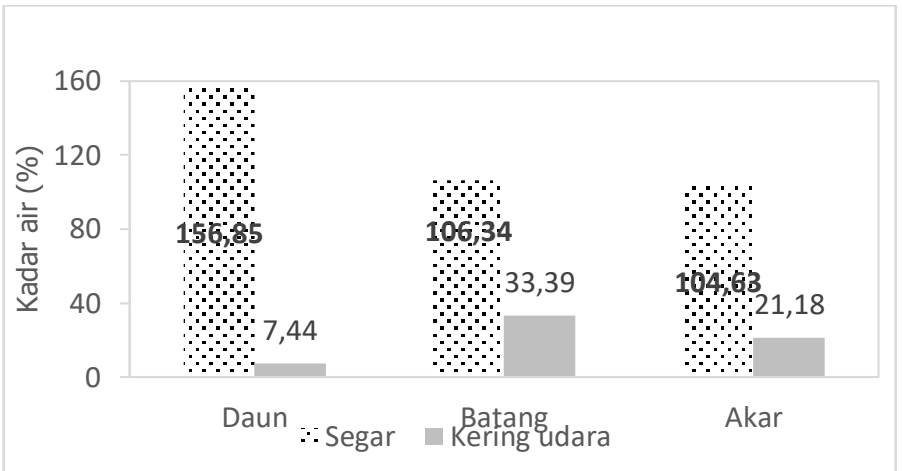

Gambar 2. Kadar air segar dan kadar air kering udara tanaman pasak bumi umur 7 tahun.

\section{Perbandingan Akar dan Batang}

Produk perdagangan Pasak Bumi pada umumnya menggunakan bahan baku bagian akarnya. Hal ini disebabkan oleh kandungan senyawa bioaktif dan kegunaan dari akar pasak bumi. Akar pasak bumi mengandung 65 senyawa bioaktif (Kuo et al., 2004) yang dapat digunakan untuk antitumor (Al-Salahi et al., 2014), antimalaria (Katib et al., 2015), efek menjaga kesehatan hati (Boya, 2011; Adikusuma \& Bachri, 2014), meningkatkan kualitas sperma (Ismail \& Imran, 2010), menurunkan indeks ulkus lambung, asam bebas getah lambung dan total asam lambung (Kosala, 2010), osteoporosis (Effendy et al., 2012), antiimflamasi (Varghese et al., 2013), antiprotozoa (Girish et al., 2015).

Informasi perbandingan antara panjang akar dan batang diharapkan dapat digunakan untuk memperkirakan panjang akar hasil panenan yang akan diperoleh dengan hanya melakukan pengukuran tinggi tanaman. Kasus ini berlaku bila tanaman pasak bumi tumbuh secara normal. Perbandingan akar dan batang tanaman pasak bumi umur 7 tahun disajikan pada Gambar 3. Sampel tanaman pasak bumi umur 7 tahun dikelompokan dalam 4 kelas yaitu tinggi tanaman kurang dari $100 \mathrm{~cm}$, antara $100-150 \mathrm{~cm}$, antara 150-200 cm dan lebih dari $200 \mathrm{~cm}$ (berdasarkan data yang diperoleh di lapangan). Kelompok tanaman ini dilakukan untuk lebih merinci hasil perbandingan pada umur yang sama namun memiliki tinggi tanaman yang berbeda.

Rata-rata perbandingan akar dan batang tanaman pasak bumi umur 7 tahun adalah 0,65 dengan kecenderungan menurun seiring peningkatan tinggi tanaman. Tanaman dengan tinggi lebih dari $200 \mathrm{~cm}$ memiliki perbandingan akar dan batang yang terkecil yaitu 0,38. Ini menunjukkan bahwa pertumbuhan akar dan tinggi tanaman pasak bumi umur 7 tahun memiliki perbandingan $1: 3$. Pertumbuhan tinggi batang 3 kali lebih cepat dari pertumbuhan panjang akar. Sementara yang terjadi di masyarakat adalah eksploitasi akar yang berlebihan yang digunakan sebagai bahan baku pada industri obat pasak bumi dan mengakibatkan potensi tanaman ini semakin berkurang di hutan alam. Tanaman E. longifolia merupakan tanaman dengan pertumbuhan yang lambat, berbunga dan berbuah dengan jumlah sedikit, sehingga penggunaan bibit cabutan menjadi penting dalam penanaman (Mohamed et al., 2015). 


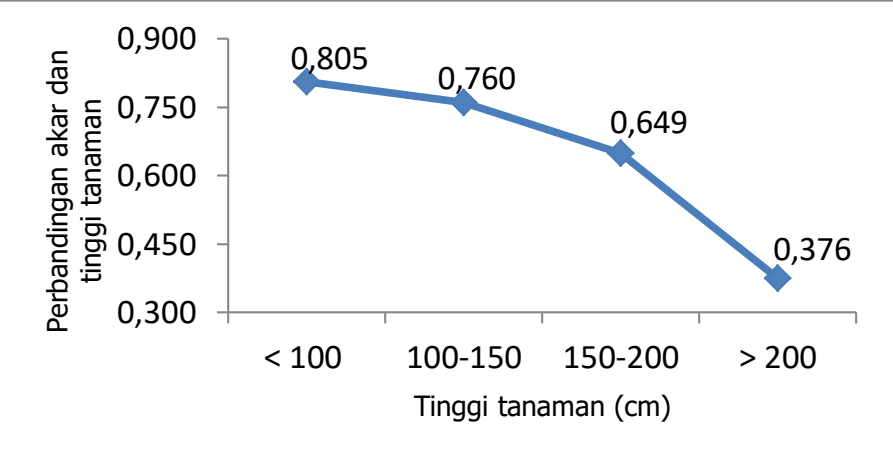

Gambar 3. Perbandingan panjang akar dan tinggi batang tanaman pasak bumi umur 7 tahun.

\section{Rendemen Simplisia}

Rata-rata berat keseluruhan 1 tanaman pasak bumi umur 7 tahun adalah 0,57 kg basah dan $0,34 \mathrm{~kg}$ kering udara. Rata-rata berat basah pasak bumi umur 7 tahun perbagian yaitu daun (73 g), ranting (38 g), batang (298 g) dan akar $(166 \mathrm{~g})$, sedang rata-rata berat kering udara pasak bumi umur 7 tahun perbagian yaitu daun (30 g), ranting (16 g), batang $(200 \mathrm{~g})$ dan akar $(97 \mathrm{~g})$. Rendemen perbagian tanaman pasak bumi umur 7 tahun dan berat kering oven pada akar, batang dan daun disajikan pada Tabel 1. Informasi rendemen perbagian ini diperlukan untuk mengetahui bahan baku tanaman pasak bumi segar di lapangan yang akan dipanen disesuaikan dengan jumlah bahan baku produksi yang diperlukan. Berdasarkan hasil tersebut, maka untuk mendapatkan bahan baku daun kering udara $1 \mathrm{~kg}$ perlu memanen $\pm 3 \mathrm{~kg}$ daun segar (perbandingan 1:3) dan untuk mendapatkan bahan baku akar atau batang kering udara $1 \mathrm{~kg}$ perlu memanen $\pm 2 \mathrm{~kg}$ akar atau batang segar (perbandingan 1:2). Sehingga kita dapat mengatur bahan baku tanaman pasak bumi yang segar untuk bahan baku produksi produknya.

Tabel 1. Rendemen perbagian dan berat kering oven tanaman pasak bumi umur 7 tahun

\begin{tabular}{lcccccc}
\hline \multicolumn{1}{c}{ Tinggi tanaman } & \multicolumn{2}{c}{ Rendemen per bagian (\%) } & \multicolumn{3}{c}{ Berat kering oven $(\mathrm{g})$} \\
\cline { 2 - 7 } \multicolumn{1}{c}{ Daun } & Batang & Akar & Daun & Batang & Akar \\
\hline \hline$<100$ & 39,58 & 50,79 & 52,21 & 13,91 & 70,15 & 44,08 \\
$100-150$ & 38,97 & 47,52 & 49,77 & 22,21 & 76,32 & 51,77 \\
$150-200$ & 37,13 & 48,48 & 45,88 & 35,93 & 193,42 & 109,26 \\
$>200$ & 39,33 & 47,23 & 47,43 & 36,01 & 211,41 & 97,18 \\
Rata-rata & 38,75 & 48,50 & 48,82 & 27,01 & 137,82 & 75,57 \\
\hline
\end{tabular}

Informasi rendemen total bagian tanaman pasak bumi diperlukan untuk mengetahui bagian tanaman yang memiliki potensi tertinggi untuk bahan baku produksi produk, sehingga dapat digunakan sebagai bahan pertimbangan dalam pemanfaatannya dan meminimalkan limbah bahan baku. Rendemen tertinggi bahan baku produksi terdapat pada bagian batang dari semua kelas tinggi tanaman yang rata-ratanya mencapai $52,46 \%$ (Gambar 4). Tingginya rendemen batang pasak bumi ini berpotensi sebagai bahan baku obat herbal, diantaranya ekstrak batang pasak bumi memiliki aktivitas antikanker yang mengandung senyawa 9, 10-dimethoxycanthin-6-one, 10-hydroxy-9-methoxycanthin-6-one dan dihydroniloticin (Miyake et al., 2010), antimalaria dan antimikroba (Bhat \& Karim, 2010).

Kisaran rendemen batang antara 46,92-58,17\%, akar (26,55-32,37\%), dan daun $(9,35-13,77 \%)$ dari berat total tanaman dan sisanya adalah bagian ranting. Variasi yang terjadi pada batang menunjukkan bahwa persentase rendemen berkecenderungan semakin meningkat seiring tinggi tanaman, namun sebaliknya pada bagian akar dan daun semakin menurun. Berdasarkan informasi tersebut, plot tanaman pasak bumi yang telah ditanam oleh 
B2P2EHD dengan jumlah tanaman sebanyak 4.356 perha (jarak tanam $1,5 \mathrm{~m} \times 1,5 \mathrm{~m}$ ) memiliki potensi rendemen berat kering udara keseluruhan yang dapat diperoleh dari tanaman umur 7 tahun adalah $1.481 \mathrm{~kg} / \mathrm{ha}$.

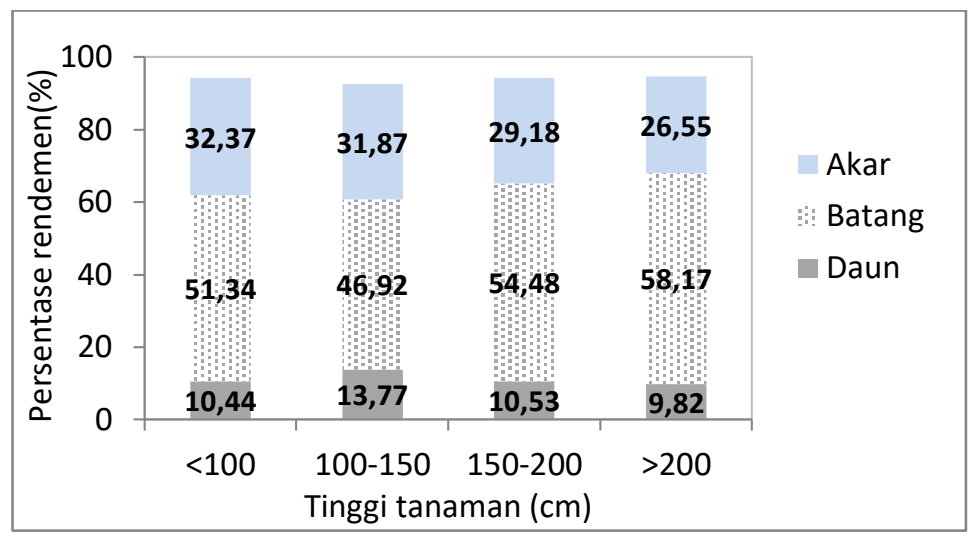

Gambar 4. Persentase rendemen daun, batang dan akar tanaman pasak bumi umur 7 tahun.

\section{Rendemen Ekstrak}

Penentuan rendemen berfungsiuntuk mengetahui jumlah metabolit sekunder yang terbawa oleh pelarut, tetapi komponen yang terkandung tidak dapat diketahui (Nurwendari, 2014). Rendemen ekstrak Pasak bumi (E. longifolia) disajikan pada Tabel 2. Rendemen ekstrak tertinggi terdapat pada maserasi dengan pelarut air. Hal ini menunjukkan bahwa air merupakan pelarut yang lebih banyak melarutkan senyawa-senyawa kimia yang terdapat dalam tanaman Pasak Bumi. Pelarut air bersifat lebih polar dari etanol sehingga dapat menarik senyawa yang memiliki tingkat kepolaran tinggi, pelarut air dan etanol juga diperbolehkan dalam penggunanya untuk produksi pangan dan farmasi agar produk yang dihasilkan aman untuk konsumsi (Iswantini et al., 2009). Persentase rendemen ekstrak tertinggi terdapat pada bagian daun dengan pelarut air. Ini menunjukkan bahwa apabila daun dimanfaatkan sebagai bahan baku obat herbal memiliki potensi yang relatif tinggi.

Tabel 2. Rendemen ekstrak Pasak Bumi (E. longifolia) bagian akar, batang dan daun.

\begin{tabular}{ccccc}
\hline Ekstrak & Pelarut & MF & BeratEkstrak $(\mathrm{g})$ & Rendemen (\%) \\
\hline \hline Akar & Etanol & 0,9355 & 0,1927 & 1.0284 \\
Batang & Etanol & 0,9332 & 0,1788 & 0.9570 \\
Daun & Etanol & 0,8868 & 0,1847 & 3,4318 \\
\hline Akar & Air & 0,9355 & 0.4896 & 10.4673 \\
\hline Batang & Air & 0,9332 & 0.3016 & 6.4638 \\
\hline Daun & Air & 0,8867 & 0,4958 & 11,1830 \\
\hline
\end{tabular}

\section{Fitokimia Pasak Bumi}

Hasil uji fitokimia untuk ekstrak Pasak bumi bagian akar, batang dan daun disajikan pada Tabel 3 menunjukkan bahwa bahan bioaktif pada ekstrak akar dan batang lebih banyak larut pada pelarut air dan etil asetat dibandingkan dengan pelarut etanol, sedangkan pada ekstrak daun engan pelarut air dan pelarut etanol lebih banyak melarutkan bahan bioktif dibandingkan dengan pelarut etil asetat. Bahan bioaktif yang terkandung dalam ekstrak akar dan batang ada 5 komponen yaitu alkaloid, tanin, triterpenoid, karotenoid dan kumarin, sedangkan bahan bioaktif yang terkandung dalam ekstrak daun lebih banyak (6 komponen) yaitu flavonoid, saponin, tanin, triterpenoid, karotenoid, dan kumarin.

Tanin, triterpenoid, karotenoid dan kumarin merupakan komponen yang terdeteksi pada semua bagian tanaman. Mohamed et al. (2015) menyatakan bahwa ekstrak pelarut air 
dari E. longifolia mengandung tanin, polisakarida, glikoprotein dan mucopolisakarida. Ekstrak akar $E$. longifolia untuk pelarut air mengandung 7 komponen qussinoid dan 3 komponen alkaloid, sedangkan ekstrak dengan pelarut etil asetat mengandung 7 komponen quassinoid, $1 \beta$-carboline alkaloids dan 1 canthin-6-one alkaloid (Girish et al., 2015), dimana canthin-6one ini memiliki aktivitas antimalaria dan antiparasit. Selain itu, hasil skrining fitokimia dari batang $E$. longifolia untuk pelarut etil asetat mengandung alkaloid, senyawa fenolik, flavonoid, terpenoid, cardiac glycosida dan protein (Khanam et al., 2015).

Alkaloid berkhasiat sebagai antimalaria, antidiabetes, antimikroba dan antidiare (Ningrum et al., 2016). Flavanoid merupakan salah satu unsur alami yang sering ditemukan pada tumbuhan yang diketahui menunjukan aktivitas antioksidan, sehingga berefek pada nutrisi dan kesehatan manusia (Suhartono et al., 2012). Triterpenoid memiliki aktivitas sebagai antijamur, antibakteri, antivirus, pengobatan kerusakan hati, gangguan menstruasi dan pengobatan penyakit diabetes (Asih et al., 2010). Tanin memiliki antivitas sebagai antioksidan, antimikroba dan antiimflamasi (Ibrahim et al., 2015).

Tabel 3. Hasil uji fitokimia ekstrak akar, batang dan daun E. longifolia.

\begin{tabular}{lccccccccc}
\hline Ekstrak & \multicolumn{4}{c}{ Akar } & \multicolumn{4}{c}{ Batang } & \multicolumn{3}{c}{ Daun } \\
\hline \hline Pelarut & etanol & air & Etil asetat & etanol & air & Etil asetat & etanol & air & Etil asetat \\
\hline \hline Alkaloid & - & + & ++ & - & +++ & + & - & - & - \\
Flavonoid & - & - & - & - & - & - & + & + & - \\
Saponin & - & - & - & - & - & - & - & ++ & - \\
Tanin & ++ & ++ & - & + & + & - & + & ++ & - \\
Steroid & - & - & - & - & - & - & - & - & - \\
Triterpenoid & + & + & ++ & + & + & + & ++ & + & +++ \\
Karotenoid & - & - & + & - & - & + & + & - & - \\
Kumarin & + & ++ & + & + & + & + & + & + & + \\
\hline \multicolumn{1}{r}{ Keterangan } & - & & + & + & + & & & &
\end{tabular}

\section{KESIMPULAN}

Tanaman pasak bumi umur 7 tahun asal KHDTK Samboja perpohon memiliki ratarata rendemen $46,41 \%$ dengan rata-rata rendemen masing-masing pada akar $(13,80 \%)$, batang $(25,05 \%)$ dan daun $(4,87 \%)$, sisanya ranting. Rendemen tertinggi tanaman pasak bumi tersebut terdapat pada bagian batang. Persentase rendemen batang menunjukkan kecenderungan yang semakin meningkat seiring tinggi tanaman dan sebaliknya semakin menurun pada akar dan daun. Ekstrak akar, batang dan daun dengan pelarut air memiliki rendemen yang lebih tinggi dibandingkan dengan pelarut etanol. Bahan bioaktif yang terkandung dalam ekstrak akar dan batang adalah alkaloid, tanin, triterpenoid, karotenoid dan kumarin, sedangkan bahan bioaktif yang terkandung dalam ekstrak daun adalah flavonoid, saponin, tanin, triterpenoid, karotenoid, dan kumarin. Akar, batang dan daun memiliki potensi sebagai antimalaria, antidiabetes, antidiare, antijamur, antibakteri, antivirus, pengobatan kerusakan hati, gangguan menstruasi, antioksidan, dan antiimflamasi. Optimalisasi bahan baku perlu dilakukan untuk memaksimalkan pengolahan dan meminimalkan limbah pemanenan tanaman pasak bumi.

\section{UCAPAN TERIMA KASIH}

Penelitian ini didanai dari DIPA Balai Besar Penelitian dan Pengembangan Ekosistem Hutan Dipterokarpa. Penulis mengucapkan terima kasih kepada Taufiqurrohman, S.Hut., MPA selaku Kepala Seksi Data, Informasi dan Sarana Penelitian Balai Penelitian dan Pengembangan Teknologi Konservasi Sumber Daya Alam Samboja yang telah membantu dalam memelihara dan pengambilan sampel tanaman pasak bumi. 


\section{DAFTAR PUSTAKA}

Abdulghani, M., Hussin, A. H., Sulaiman, S. A., \& Chan, K. L. 2012. The Ameliorative Effects of Eurycoma longifolia Jack on Testosterone-Induced Reproductive Disorders in Female Rats. Reproductive Biology 12(2): 247-255.

Achmad, B. 2016. Efektivitas Rooton-F, Air Kelapa Muda dan Ekstrak Bawang Merah dalam Merangsang Pertumbuhan Stek Batang Pasak Bumi. Jurnal Hutan Tropis 4(3): 224 231.

Adikusuma, W., \& Bachri, M. S. 2014. Efek Hepatoprotektif Serbuk Akar Pasak Bumi (Eurycoma longifolia Jack.) Dilihat dari Aktivitas Sgpt-Sgot Tikus Jantan yang Diinduksi $\mathrm{CCl}_{4}$. Pharmaçiana 4(2): 165-170.

Adinugroho, W. C., Setiabudi, D., \& Gunawan, W. 2007. Potensi dan Hambatan Pengelolaan Kawasan Hutan Dengan Tujuan Khusus (KHDTK) Penelitian Samboja. Prosiding Seminar Pemanfaatan HHBK dan Konservasi Biodiversitas Menuju Hutan Lestari, Balikpapan, 31 Januari 2007: 108-118.

Adri, D., \& Hersoelistyorini, W. 2013. Aktivitas Antioksidan dan Sifat Organoleptik Teh Daun Sirsak (Annona Muricata Linn.) Berdasarkan Variasi Lama Pengeringan. Jurnal Pangan dan Gizi 4(7): 1-12.

Al-Salahi, O. S. A., Ji, D., Majid, A. M. S. A., Kit-Lam, C., Abdullah, W. Z., Zaki, A., Din, S. K. K. J., Yusoff, N. M., \& Majid, A. S. A. 2014. Anti-tumor Activity of Eurycoma longifolia Root Extracts Against K-562 Cell Line: in Vitro and in Vivo Study. PLOS ONE $9(1): 1-14$.

Asih, I. A. R. A., Gunawan, I. W. G., \& Ariani, N. M. D. 2010. Isolasi dan Identifikasi Senyawa Golongan Triterpenoid dari Ekstrak n-heksana Daun Kepuh (Stercullia foetida L.) serta Uji Aktivitas Antiradikal Bebas. Jurnal Kimia 4(2): 135-140.

Balebu, E., Boer, C., \& Sukaton, E. 2002. Identifikasi dan Analisis Kimia Jenis-jenis Pakan Rusa Sambar (Cervus unicolor Brookei) di Areal Penangkaran Rusa Kabupaten Pasir Propinsi Kalimantan Timur. Equator 1(2): 75-101.

Bhat, R., \& Karim, A. A. 2010. Tongkat Ali (Eurycoma longifolia Jack): A Riview on Its Ethnobotany Pharmacological Importance. Fitoterapia 81:669-679.

Boya, R. D. 2011. Pengaruh Ekstrak Akar Pasak Bumi (Eurycoma longifolia) terhadap Struktur Histologi Sel Hepar Mencit yang Dipaparkan Parasetamol. Skripsi. Fakultas Kedokteran universitas Sebelas Maret. Surakarta.

BPOM. 2014. Peraturan Kepala Badan Pengawas Obat dan Makanan Nomor 12 Tahun 2014 Tentang Persyaratan Mutu Obat Tradisional. Badan Pengawas Obat dan Makanan. Jakarta.

Cahyono, D. D. N., \& Rayan. 2016. Pengaruh Komposisi Media dan Perbedaan Populasi pada Pertumbuhan Cabutan Pasak Bumi. Jurnal Penelitian Ekosistem Dipterokarpa 2(2): 67-72.

Effendy, M. N., Mohamed, N., Muhammad, N., Mohamad, I. N., \& Shuid, A. N. 2012. Eurycoma longifolia : Medicinal Plant in the Prevention and Treatment of Male Osteoporosis due to Androgen Deficiency. Evidence-Based Complementary and Alternative Medicine, Hindawi Publishing Corporation, 1-9. Doi: $10.1155 / 2012 / 125761$.

Farouk, A. E. A., \& Benafri, A. 2007. Antibacterial Activity of Eurycoma longifolia Jack. A Malaysian Medicinal Plant. Saudi Med J 28(9): 1422-1424.

Fitriani, S., Astiani, D., \& Wahdina. 2017. Perbanyakan Tanaman Pasak Bumi (Eurycoma longifolia Jack) secara Generatif dan Vegetatif di Persemaian. Jurnal Hutan Lestari 5(1): 113-120.

Girish, S., Kumar, S., \& Aminudin, N. 2015. Tongkat Ali (Eurycoma longifolia): A Possible Therapeutic Candidate Againts Blastocystis sp. Parasites and Vectos (332): 1-7. 
Hasibuan, S., Suhesti, E., \& Insusanty, E. 2016. Kajian Ekologi Pasak Bumi (Eurycoma longifolia Jack) dan Pemanfaatan oleh Masyarakat di Sekitar Hutan Larangan Adat Rumbio, Kabupaten Kampar Provinsi Riau. Wahana Forestra Jurnal Kehutanan 11(2): 112-126.

Heriyanto, N. M., Sawitri, R., \& Subiandono, E. 2006. Kajian Ekologi dan Potensi Pasak Bumi (Eurycoma longifolia Jack.) di Kelompok Hutan Sungai Manna-Sungai Nasal, Bengkulu. Buletin Plasma Nutfah 12(2): 69-75.

Ibrahim, A. M., Lawal, B., Tsado, N. A., Yusuf, A. A., \& Jimoh, A. M. 2015. Phytochemical screening and GC-MS determination of Bioactive Consitituents from Methanol Extract of Senna occidentalis. Journal of Coastal Life Medicine 3(12): 992-995.

Ikalinus, R., Widyastuti, S. K., \& Setiasih, N. L. E. 2015. Skrining Fitokimia Ekstrak Etanol Kulit Batang Kelor (Moringa oleifera). Indonesia Medicus Veterinus 4(1): 71-79.

Ismail, M., \& Imran, M. K. 2010. Eurycoma longifolia Jack in Managing Idiopathic Male Infertility. Asian Journal of Andrology 12: 376-380.

Iswantini, D., Syabirin, G., \& Affandi, Y. 2009. Daya Hambat Ekstrak Air dan Etanol Keladi Tikus (Typhonium flagelliforme) terhadap Enzim Tirosin Kinase secara in Vitro. Prosiding Seminar Nasional Sains II: 14 November 2009, Bogor. Fakultas Matematika Dan Ilmu Pengetahuan Alam, Institut Pertanian Bogor: 47-58.

Kartikawati, S. M. 2014. Konservasi Pasak Bumi (Eurycoma longifolia Jack) Ditinjau dari Aspek Tata Niaga. Disertasi. Sekolah Pascasarjana Institut Pertanian Bogor. Bogor.

Katib, S., Ruangrungsi, N., Chaijaroenkul, W., \& Rungsihirunrat, K. 2015. Standardization Parameters, Internal Transcribed Spacer Nucleotide Sequence and Their AntiMalarial Activity of Eurycoma longifolia Jack. International Journal of Advances in Pharmacy, Biology and Chemistry 4(1): 1-6.

Katno. 2008. Penanganan Pasca Panen Tanaman Obat. Balai Besar Penelitian dan Pengembangan Tanman Obat dan Obat Tradisional. Depkes.

Khanam, Z., Wen, C. S., \& Bhat, I. U. H. 2015. Phytochemical Screening and Antimicrobial Activity of Root and Stem Extracts of Wild Eurycoma longifolia Jack (Tongkat Ali). Journal of King Saud University - Science 27: 23-30.

Kosala, K. 2010. Uji Efek Proteksi Akar Pasak Bumi (Eurycoma longifolia) terhadap Ulkus Lambung Tikus yang Diinduksi dengan Ligasi Pilori. Media Sains 2(1): 27-34.

Kuo, P. C., Damu, A. G., Lee, K. H., \& Wu, T. S. 2004. Cytotoxic and Antimalarial Constituents from The Roots of Eurycoma longifolia. Bioorganic and Medicinal Chemistry 12(3): 537-544.

Miyake, K., Tezuka, Y., Awale, S., Li, F., \& Kadota, S. 2010. Canthin-6-one Alkaloids and a Tirucallanoid from Eurycoma longifolia and Their Cytotoxic Activity against a Human HT-1080 Fibrosarcoma Cell Line. Natural Product Communications 5(1): 17-22.

Mohamed, A. N., Vejayan, J., \& Yusoff, M. M. 2015. Review on Eurycoma longifolia Pharmacological and Phytochemical Properties. Journal of Applied Sciences 15(6): 831-844.

Musa, Y., Mansor, P., \& Ramli, M. (2005). Pertumbuhan dan Prestasi Hasil Akar Tongkat Ali di Bawah Sistem Tanaman Terbuka di Kesedar Mengkebang. Buletin Teknologi Tanaman, 27-33.

Ningrum, R., Purwanti, E., \& Sukarsono. 2016. Identifikasi Senyawa Alkaloid Dari Batang Karamunting (Rhodomyrtus tomentosa) sebagai Bahan Ajar Biologi untuk SMA Kelas X. Jurnal Pendidikan Biologi Indonesia 2(3): 231-236.

Nurani, L. H. 2011. Mekanisme Molekuler Kemopreventif dan Anti Kanker Senyawa Aktif Akar Pasak Bumi (Eurycoma longifolia Jack) Kajian In Vitro Pada Sel T47D dan In Vivo Pada Kanker Payudara Pada Tikus SD Yang Diinduksi DMBA. Disertasi. Universitas Gadjah Mada. Yogyakarta. 
Nurwendari, W. 2014. Teknik Ekstraksi Terbaik untuk Isolasi Kaemferol dari Daun Sirsak (Annona muricata). Skripsi. Fakultas Matematika dan Ilmu Pengetahuan Alam. Departemen Kimia, Institut Pertanian Bogor. Bogor.

Panjaitan, R. G. P., Jayuska, A., Harahap, Z., \& Zakiah, Z. 2009. Pemberian Akar Pasak Bumi (Eurycoma longifolia Jack.) pada Induk Laktasi untuk Meningkatkan Bobot Badan Anak Mencit. MAKARA SAINS 13(2): 195-199.

Pratomo, H. 2012. Kinerja Pasak Bumi (Eurycoma longifolia Jack) dalam Peningkatan Kualitas Reproduksi Tikus (Rattus norvegicus) Jantan. Tesis. Pascasarjana Institut Pertanian Bogor. Bogor.

Rayan, Suastati, L., Armansah, \& Supriadi. 2010. Budidaya Tumbuhan Obat Jenis Pasak Bumi (Eurycoma sp) pada Ekosistem Hutan Dipterocarpaceae. Laporan Hasil Penelitian. Balai Besar Penelitian Dipterokarpa. Samarinda.

Riyani, C. 2016. Efektifitas Metode Pengeringan pada Pembuatan Simplisia Akar Pasak Bumi (Eurycoma longifolia Radix). Jurnal Sains dan Terapan Politeknik Hasnur 04(1): 2026.

Rosmaina, Zulfahmi, Sutejo, P., Ulfiatun, \& Maisupratina. 2015. Induksi Kalus Pasak Bumi (Eurycoma longifolia Jack) Melalui Eksplan Daun dan Petiol. Jurnal Agroteknologi 6(1): 33-40.

Safrina, D., \& Priyambodo, W. J. 2018. Pengaruh Ketinggian Tempat Tumbuh dan Pengeringan terhadap Flavonoid Total Sambang Colok (Iresine herbstii). Jurnal Penelitian Pascapanen Pertanian 15(3): 147-154.

Sani, R. N., Nisa, F. C., Andriani, R. D., \& Maligan, J. M. 2014. Analisis Rendemen dan Skrining Fitokimia Ekstrak Etanol Mikroalga Laut Tetraselmis chuii. Jurnal Pangan dan Agroindustri 2(2): 121-126.

Sembiring, N. V. N. 2009. Pengaruh Kadar Air dari Bubuk Teh Hasil Fermentasi terhadap Kapasitas Produksi pada Stasiun Pengeringan di Pabrik Teh PTPN IV Unit Kebun Bah Butong. Karya IImiah. Program Studi Diploma-3 Kimia Industri, Universitas Sumatera Utara. Medan.

Senthilmurugan, Sekar, R., Suresh, K., \& Balamurugan, S. 2013. Phytochemical Screening, Enzyme and Antibacterial Activity Analysis if Endophytic Fungi Botrytis sp. Isolated from Ficus Benghalensis (L.). International Journal Of Pharmaceutical Research and BioScience 2(4): 264-273.

Setyowati, F. M. 2010. Etnofarmakologi dan Pemakaian Tanaman Obat Suku Dayak Tunjung di Kalimantan Timur. Media Litbang Kesehatan XX(3): 104-112.

Siburian, J., \& Marlinza, R. 2009. Efek Pemberian Ekstrak Akar Pasak Bumi (Eurycoma longifolia Jack) pada Tahap Prakopulasi terhadap Fertilitas Mencit (Mus musculus L.) Betina. Biospecies 2(2): 24-30.

Silalahi, M., \& Nisyawati. 2015. Etnobotani Pasak Bumi (Eurycoma longifolia) pada Etnis Batak, Sumatera Utara. Prosiding Seminar Nasional Masyarakat Biodiversitas Indonesia 1(4): 743-746.

SNI 3945. 2016. Teh hijau. Standar Nasional Indonesia. Badan Standardisasi Nasional. Jakarta.

Suharti, T., Bramasto, Y., \& Yuniarti, N. 2013. Kajian Pengembangan Tanaman Obat dalam Sistem Agroforestri. Prosiding Seminar Agroforestri 2013. Kerjasama Balai Penelitian Teknologi Agroforestry - Fak. Pertanian Univ. Brawijaya - World Agroforestry Centre - Masyarakat Agroforestri Indonesia. Ciamis: 66-71.

Suhartono, E., Viani, E., Rahmadhan, M. A., Gultom, I. S., Rakhman, M. F., \& Indrawardhana, D. 2012. Total flavonoid and Antioxidant Activity of Some Selected Medicinal Plants in South Kalimantan of Indonesian. APCBEE Procedia 4: 235-239.

Supartini, \& Maharani, R. 2017. Teknik Pengolahan Pasak Bumi sebagai Biomedicine dan 
Biocosmetic. Laporan Hasil Penelitian. Balai Besar Penelitian dan Pengembangan Ekosistem Hutan Dipterokarpa. Samarinda.

Susilowati, A., Supriyanto, A., Siregar, I. Z., \& Subiakto, A. 2012. Perbanyakan Tanaman Pasak Bumi (Eurycoma longifolia Jack) Melalui Teknik Stek Pucuk. FORESTA Indonesian of Jurnal Forestry 1(1): 25-29.

Tran, T. V. A., Malainer, C., Schwaiger, S., Atanasov, A. G., Heiss, E. H., Dirsch, V. M., \& Stuppner, H. 2014. NF-kB Inhibitors from Eurycoma longifolia. Journal of Natural Products 77(3): 483-488.

Varghese, C. P., Ambrose, C., Jin, S. C., Lim, Y. J. Keisaban. 2013. Antioxidant and Antiinflammantory Activity of Eurycoma longifolia Jack, A Tradisional Medicine Plant in Malaysia. International Journal of Pharmaceutical Science and Nanotechnology 5(4): 1875-1878.

Widiyantoro, A. 2014. Metabolit Sekunder Prospektif dari Famili Simaroubaceae. Jurnal Penelitian Saintek 19(2): 14-22.

Wulandari, Z., Ugiarto, M., \& Hairah, U. 2017. Sistem Informasi Obat-obatan Herbal. Prosiding Seminar IImu Komputer dan Teknologi informasi 2(1): 227-234.

Yusuf, H., Mustofa, Wijayanti, M. A., Susidarti, R. A., Asih, P. B. S., Suryawati, \& Sofia. 2013. A New Quassinoid of Four Isolated Compound From Extract Eurycoma longifolia Jack, Roots and Their In-Vitro Antimalarial Activity. International Journal of Research in Pharmaceutical and Biodimedical Sciences 4(3): 727-734.

Zuhud, E. A. ., \& Hikmat, A. 2009. Hutan Tropika Indonesia sebagai Gudang Obat Bahan Alam Bagi Kesehatan Mandiri Bangsa. Dalam Bunga Rampai Biofarmaka Kehutanan Indonesia: dari Tumbuhan Hutan untuk Keunggulan Bangsa dan Negara. Editor Djaban Tinambunan dan Ari Wibowo. Penerbit Pusat Penelitian dan Pengembangan Hutan Tanaman, Badan Penelitian dan Pengembangan Kehutanan, Kementerian Kehutanan. Bogor: 17-28. 